\title{
A Critical Analysis of the Relations between Organized Civil Society and Democratizing of Global Governance
}

\author{
Ni Wang \\ School of Language, Literature and Law, Xi'an University of Architecture and Technology \\ No. 13 Yanta Road, Xi'an 710055, China \\ Tel: 86-29-8220-1048Ｅ-mail: jennytkw2002@yahoo.com.cn
}

\begin{abstract}
In this paper, the author will discuss two popular terms, i.e. organized civil society and global governance and their relations. The paper is mainly about organized civil society (international non-governmental organizations) and democracy in global governance. First, the author will provide a few related definitions. These terms, although are highly contested, need to be identified to avoid confusion and internal coherence. Then the author will critically discuss the relations between organized civil society and the democratizing of global governance. Finally, a conclusion about the role of organized civil society in democratizing global governance will be drawn.
\end{abstract}

Keywords: Organized civil society, INGO, Global governance, Globalization, Democracy

\section{Related terms}

\subsection{Globalization}

Over the years, globalization has become one of the main themes of the world. Although there has been much contest about the term, i.e. whether it is good or harmful, or even whether it is a real phenomenon or only an analytical artifact, there is no doubt that globalization, which was originally caused by four fundamental forms of capital movement throughout the global economy (human capital, finance capital, resource capital and power capital), has entered into nearly every aspect of our life, and almost everywhere of the world.

\subsection{Civil society}

Civil society, a term with a long history, has been much developed in the past few decades. Generally, civil society refers to "the totality of voluntary civic and social organizations and institutions that form the basis of a functioning society as opposed to the force-backed structures of a state (regardless of that state's political system)" (Simai, 2006). There are a number of examples of civil society, such as private voluntary organizations, peoples' organizations, civic groups, religious organizations and non-governmental organizations, which will be talked about in details below.

\subsection{Organized civil society}

As a positive definition, Scholte (2000, p. 175) offers the following:

“...activities are considered to be part of civil society when they involve a deliberate attempt - from outside the state and the market, and in some other organized fashion - to shape policies, norms and/or deeper social structures. In a word, civil society exists when people make concerted efforts through voluntary associations to mould rules: both official, formal, legal arrangements and informal social constructs. 'Civil society' is the collective noun, while 'civic' groups, organizations, and so on, are the individual elements within civil society."

There is another definition:

"Organized civil society is "the totality of all individuals and groups in society who are to acting as participants in any government institutions." (Willetts, 2005, p. 426)

As what is stated earlier, the definition of organized civil society is highly contested. Apart from the above definitions, there are still other definitions by different scholars. However, in this paper, organized civil society refers to international non-governmental organizations (INGOs).

\subsection{INGOs}

Before defining the term INGO, it is necessary to define "NGO":

"A non-governmental organization (NGO) is an organization that is not part of a government and was not founded by states." (Wikipedia, 2009) NGOs are definitely independent of governments. According to this definition, NGOs also include profit corporations. However, this term normally refers to noncommercial groups that deal with social, cultural, legal and environmental issues. Generally speaking, NGOs are funded from 
private sources and are non-profit organizations. The objectives of NGOs vary from the aspects of politics to philosophy. However, most of them are founded to further the political or social goals of their members and usually, their goals lie in protecting natural environment, encouraging the observance of human rights, improving the welfare of the disadvantaged and representing a corporate agenda. Today's NGOs have gradually developed in the past 200 years. International Committee of the Red Cross, which was founded in 1863, is among the earliest NGOs. The phrase "non-governmental organization" can be traced back from Article 71 of Charter 10 of the United Nations Charter in 1954 when the United Nations was established. The importance of NGOs was realized by people from the globalization in the $20^{\text {th }}$ century, in which a great number of problems existing inter states needed to be solved. At that time, international treaties and international organizations were regarded as being too centered on the interests of capitalist enterprises. Thus NGOs have developed to emphasize humanitarian issues, developmental aid and sustainable development, with the purpose of counterbalance this trend. What is needed to be paid attention is that NGOs are not legal entities, with the exception of International Committee of the Red Cross, which is provided in international law based on the Geneva Convention.

INGO is one of the many types of NGO, which stands for "international non-governmental organization". The definition of INGO was first given in resolution 288 (X) of ECOSOC on February 27, 1950: it is defined as "any international organization that is not founded by an international treaty". (Wikipedia, 2009) Examples of INGOs are Cooperative for Assistance and Relief Everywhere (CARE) founded in 1945, Mercy Corps founded in 1979, Greenpeace founded in 1971 and International Committee of the Red Cross (ICRC) founded in 1864.

\subsection{Global governance}

Global governance is a phenomenon that came into being with globalization. Generally, global governance refers to "political interaction aimed at solving problems that affect more than one state or region when there is no power of enforcing compliance" (Wikipedia, 2009). At present, with the deepening and widening of globalization, more and more social relations substantially transcend territorial geography, thus territorialist governance has become impracticable. It is now impossible for national and local governments to regulate and control global phenomena. The need of dealing with international relations and solve global problems have become more and more obvious when there is a lack of "world government", namely an international analogue of a domestic governance. In fact, there is no possibility to establish such a government because of the "state sovereignty". Therefore, there is a need to find proper ways to solve problems that affect more than one state or region, which could lead to a final consensus.

The term "global governance" is different from the traditional "governance" or more precisely "government", which more or less has a meaning of "control". "Global governance" is a descriptive term rather than a normative term, which refers to concrete cooperative problem solving arrangements. These arrangements can be both formal and informal. Thus, global governance may be defined as "the complex of formal and informal institutions, mechanisms, relationships, and processes between and among states, markets, citizens and organizations, both inter-governmental and non-governmental, through which collective interests on the global plane are articulated, rights and obligations are established, and differences are mediated." (Thomas \& Ramesh, forthcoming)

\section{The challenge of democracy in global governance}

The contemporary global governance lacks democracy legitimacy in almost its every area, such as global communications, global ecology, global markets, global money and finance, global organizations and so on. "It is no exaggeration to say that contemporary globalization has provoked a crisis of democracy." (Scholte, 2001) The crisis is caused by two major structural problems, which will be stated below, and in turn the two structural problems are reflected in a host of institutional deficiencies.

The first structural problem is the distance between supraterritorial spaces and territorial self-determination. While many social relations become more and more global, practices of democracy still keep on national. People are still used to government for democratic governance. Regardless of how democratic the governments are, the point that democratic global governance can be derived from democracy is wrong because of the nature of state. The state, which is territorially grounded, cannot be sufficient by itself as an agent of democracy vis-à-vis global relations. Therefore, we cannot rely on merely state government.

The second structural problem is the contradiction between the newly defined "demos" and the democratic mechanisms' definition of it. In recent years, with globalization, people no longer belong to only one state, thus more and more individuals tend to identify their "people" in multiple fashions in addition to the state-nation. What is more, in the growth of cosmopolitan bonds which has been arguably encouraged by globalization, people identify the demos in terms of humanity as a whole. Yet at the same time, conventional democratic 
mechanisms tend to define "the people" only in territorial-state-nation terms.

\section{Institutional deficiencies}

The above two structural problems can be reflected in all institutional sites of the governance of supraterritorial spaces on both state and inter state levels.

In terms of states, for example, most governments limit their activities in respect of global governance, including the ones with the top democratic credentials.

In the aspect of intergovernmental institutions, democracy has been even more diluted. There is little democracy in intergovernmental governance mechanisms. For instance, "transgovernmental networks of technocrats have operated almost completely outside the public eye and democratic scrutiny" (Scholte, 2001).

Suprastate institutions are even less democratic than national governments. Take the World Trade Organizations (WTO) for example, nearly one third of the 140 member states of the WTO have no permanent representation in Geneva while the abilities of some other states' deligations have been much overstretched. Similar situations exist in the IMF as well as the World Bank. The five largest shareholders hold 40 percent of the total vote according to the quota regime. Even the United Nations (UN) does not have enough democracy.

Obviously there is a democracy deficiency in today's global governance. But are there possiblities to democratise it? Are there solutions to this problem? What ways can be used to improve the present situation? One of the effecitve ways is Cosmopolitan democracy while the other one is INGOs, which will be detailed talked about below as the focus of this paper.

\section{The contributions that can be made by INGOs to democratizing global governance}

There are six potential contributions that INGOs can make to democratizing global governance.

First, INGOs can help to inform and educate the public. This is a basic one, for instance, it is impossible for people who do not understand the mandates and modus operandi of the agencies concerned or even have not heard of them to vote in the world-scale competitive multiparty elections. To help with this, what INGOs can do is preparing handbooks and information kits, producing audio-visual presentations, organizing workshops, circulating newsletters, supplying information to and attracting the attention of the mass media, maintaining websites on the Internet, and developing curricular materials for schools and institutions of higher education.

Second, INGOs can give voice to stakeholders. They can give changes to concerned parties, making it possible for them to relay information, testimonial, and analysis to governance agencies. Particularly they can help social circles to get more information through other channels (including constitutional representative assemblies). By winning more participants, INGOs can give stakeholders more power, and consequentially democratize politics.

Third, INGOs can fuel debate in and about global governance. As is known, democratic governance is greatly based on an opening for different voices, opinions and especially uninhibited discussion. What INGOs can do is to provide such a base. A great example of this is the so called "Washington Consensus", of which debate has been generated by INGOs. Also they have contributions to other fields, such as raising ecological issues, advocating qualitative assessments of poverty promoting schemes of debt reduction in the South and so on. Due to these great contributions, policy discussions have had the opportunity to become more critical and creative.

Fourth, the transparency of global governance can be increased by INGOs. There are particularly two things that INGOs can do. First, they can bring regulatory frameworks and operations into the open. The public pressure made through INGOs here helps very much. Second, because most people are not clear about the details of decision making in global governance, INGOs can interrogate and ask questions about the "transparency", such as what is made transparent, at what time, in what forms, through what channels, on whose decision, for what purpose, in whose interest, etc.

Fifth, INGOs can increase the accountability of agencies and thus promote democracy in global governance. An example of this is INGOs can have pressed for - and subsequently participated in - independent policy evaluation mechanisms for the World Bank and the IMF. Through this function, INGOs can make authorities more responsible for their actions and policies in global governance.

The sixth contribution is based upon the previous five. Because if the INGOs inform and educate the public, give voice to stakeholders, fuel the debate, increase public transparency and the accountability of agencies concerned, they will create a general basis of democratic rule: legitimacy. Legitimacy is an important factor in any governance, because when people are aware of the legitimacy of an authority, they will think that they have to obey the authority. By making the above five contributions, INGOs can lead people to become aware that global governance should guide them. At the same time, when existing governance arrangements are considered 
illegitimate, INGOs can offer a space for expression of discontent and the pursuit of change.

\section{Negative impact of INGOs on democratizing global governance}

There are not only contributions made by INGOs to democratizing global governance, but also negative impact. There are seven negative possibilities.

First, organized civil society is not intrinsically a force for democracy. Although this term carries meanings of civility and virtue, it does not always contribute to democracy in global governance. There are contributing organizations as well as destructive ones. Some groups may aim to undermine democracy, such as racists, ultra-nationalists and religious fundamentalists, which can seek to suppress the democratic rights of others.

Second, organized civil society might undermine democracy in global governance when its interventions are ill conceived in design and/ or execution. One example of this is the problems of activists. They may not have clear objectives. Also they may not understand the mandates and modus operandi of the institutions of global governance, or they may neglect key global policy areas that require democratization. Another example is that academics may fail to put theoretical models of global democracy in empirical evidence and political practicalities. What more usually happens is that low-quality initiatives in some cases cause harm rather than help including to vulnerable social circles.

Third, some agencies of global governance are ill equipped to handle organized civil society inputs, causing a loss of democracy. Their problems may be the lack of staff expertise, fund, suitable procedures or the necessary receptive attitudes to take advantage of the benefits on offer from organized civil society. In some situations, the responsibilities of failures of the contact and negotiations between INGOs and official bodies lie with the latter rather than the former. For instance, if officials do not want INGOs' interference with them, they can use different ways. They may consult the INGOs only in the later stages of decision-making steps after the main decision has been made. Or they may provide insufficient opportunities to INGOs to determine the key issues. Their attitudes can be the decisive factor of the democratizing of global governance.

Fourth, sometimes even if the inputs of organized civil society have been dealt with properly, they may have negative consequences because of the loss of the previous positive potentials of the INGOs, especially when they render services to governance agencies or take funds from them. Campaigners can be anther subjects of losing the original positive potentials. Official bodies may as well cause these negative consequences by recasting the "civil society critique" to their own purposes.

Fifth, inadequate representation in INGOs may cause destruct to democracy in global governance. Here the "inadequate representation" includes the absence of some interested parties and unequal opportunities to participate. If these happen, there might be a reduction or even enlargement of structural inequalities and arbitrary privileges which are related with class, gender, nationality, race, religion, urban versus rural location, and so on. In addition, what should pay attention to is that within organized civil society there might be Hierarchies of social power which organized civil society itself is struggling against.

Sixth, because of the fifth problem, the cultural base of the engagement of organized civil society and global governance may be narrow. Particularly western INGOs led westernized elites might probably monopolize the organized civil society in the south and the former communist countries, sometimes even unintentionally. Consequentially, organized civil society may narrow grassroots circles that could have given better voice to the diversities of world life that can be affected by global governance.

Seventh, as long as it is an organized composed of individuals or other entities, where there are leaders and members, there will be a possibility for it to be undemocratic, including INGOs, even though some of them campaign particularly for democracy in global governance. For example, some INGOs might give their members no opportunity to speak because they have not paid. Some may speak on behalf of certain constituencies but in fact they have not consulted them adequately. The leadership and some other reasons of an INGO may constrain debate. Another possibility is that on one hand INGOs ask for transparency in global governance, on the other hand they themselves do not have enough transparency. Their policy making may be quite opaque. There might be a self-selected leader, which causes not enough accountability. Such a lack of internal democracy within organized civil society can be extremely harmful to democratizing global governance.

\section{Conclusion}

As what is discussed above, organized civil society can both make contributions to and undermine the democratizing of global governance.

On the one hand, organized civil society can make great contributions to a democratization of global governance. 
What INGOs can do mainly include: informing and educating the public, giving voice to stakeholders, fueling the debate, increasing public transparency and increasing the accountability of agencies. These interventions of INGOs, if positive, can be of great importance to promoting democratizing global governance, as what we have witnessed in the past two to three decades. However, to make INOGs work more effectively and make more contributions, it is important for their members to be aware of the possibilities discussed above. Of course, it is also important to have more people, funds, information and such things.

On the other hand, there are potential democratic dangers of organized civil society. It can "pursue anti-democratic goals, employ antidemocratic means, and produce anti-democratic consequences" (Scholte, 2001). To avoid these negative potentials, we need to be cautious and demand INGOs that they should not merely assert but also demonstrate their democratic legitimacy. What needs to be paid attention is that we cannot simply deny organized civil society's role in democratizing global governance due to these potential dangers. A more critical attitude is needed.

\section{References}

Patomäki, H. (2006). Problems of democratising global governance: Time, space and the emancipatory process. [online] Available: http://cpogg.org/paper\%20amerang/Heikki\%20Patom\%E4ki.pdf (May 14, 2006)

Scholte, J.A. (2000). Global Civil Society. In Woods N. (Ed.) The Political Economy of Globalization. New York: St Martins. pp. 173-201.

Scholte, J.A., (2001). Civil Society and Democracy in Global Governance. [online] CSGR Working Paper No. 65/01, University of Warwick. Available:

http://www2.warwick.ac.uk/fac/soc/csgr/research/workingpapers/2001/wp6501.pdf/ (May 14, 2006)

Simai, M. (2006). THE CIVIL SOCIETY AND THE DEVELOPMENT PROCESS. [online] Available: http://www.menszt.hu/magyar/akademiaSimai20050210.htm (May 13, 2006)

Weiss, T. G. \& Thakur, R. (forthcoming). The UN and Global Governance: An Idea and its Prospects. Indiana: University of Indiana Press.

Wikipedia. (2009). Non-governmental organization. [online] Available:

http://en.wikipedia.org/wiki/Non-governmental_organization (May 10, 2009)

Willets, P. (2005). Transnational actors and international organizations in global politics. In Baylis, J. \& Smith, S. (Eds.), The globalization of world politics : an introduction to international relations. Oxford: OUP. 